\title{
Re St Mary, Moseley
}

Birmingham Consistory Court: Cardinal Ch, March 2011 Solar panels - listed building - planning permission

The petitioners sought a faculty authorising the installation of 48 photovoltaic solar panels on the south-facing roof of a Grade II listed church. Planning permission for the proposals had been granted by an inspector on appeal. The diocesan advisory committee did not recommend the proposals, largely on the basis that the installation of the solar panels would have an adverse visual impact. The Victorian Society and English Heritage (EH) raised objections, being concerned about the impact on the appearance of the church. EH drew to the chancellor's attention Planning Policy Statement 22: renewable energy and the policy that it contained (at paragraph 11):

planning permission for renewable energy projects should only be granted where it can be demonstrated that the objectives of designation [as a listed building] will not be compromised by the development, and any adverse effects on the qualities for which the area has been designated are clearly outweighed by the environmental and economic benefits.

The Church Buildings Council recommended the granting of a faculty for the proposals on the basis that they were essentially reversible and that the scheme fitted with the Church's environmental agenda.

With regard to the prior grant of planning permission for the proposals, the chancellor applied the principles identified by Bursell Ch in Re St Mary's, White Waltham (No 2) [2010] 3 WLR 1560, (2010) 12 Ecc LJ 122. The burden of proof in faculty proceedings lay on the petitioner and there was no presumption that, unless good reason to the contrary were shown, a faculty should be granted. The fact that planning permission had been granted would not be determinative of faculty proceedings: the consistory court was not bound by the decision of the planning authority; but the planning authority's decision could be accepted as a reasoned starting point from which to begin the consistory court's own deliberations unless the conclusions of the planning authority were demonstrated to be wrong by reasoned and cogent evidence. While there were some matters (for example, traffic) that were almost exclusively within the province of town planners, there were other matters that could and should be raised before both the planning authority and the consistory court. The matter had been properly aired before the planning inspector, and the submission of the Victorian Society and EH did not contain reasoned criticism of his decision. That amounted to a 'key failing' in respect of their submissions.

The chancellor went on to hold that he must apply the Bishopsgate questions. The saving of money and acting in accordance with the Church's 'national 
stance on ecological issues and seeking to conserve energy resources' amounted to a necessity for this purpose. The chancellor rejected EH's argument that the proposals would have a significant negative impact on the appearance of the church. The proposals would have an impact, 'but not a disastrous one' and the proposals were not irreversible. As to the third of the Bishopsgate questions, the chancellor said that he was persuaded that the proposals 'do not do as great damage' as had been suggested and that the plans were 'sound and well thought out'. The grant of planning permission was not determinative but it was persuasive. A faculty was granted subject to conditions. [Alexander McGregor]

doi:10.1017/So956618X11000640

\author{
St Michael and All Angels, Withyham \\ Chichester Consistory Court: Hill Ch, April 2011 \\ Sale of paintings - redundancy
}

The minister and churchwardens of the parish sought a faculty for the sale of a set of four fourteenth-century Italian paintings that had been gifted to the church in 1849 . The paintings were provisionally valued at between $£^{1}$ million and $f_{1.5}$ million and had been housed at a museum for 14 years. There was little meaningful connection between the paintings and the parish, they were not currently in use and nor was there any realistic prospect of them returning to the church. The sale was commended by both the diocesan advisory committee and the Church Buildings Council. The chancellor summarised the law as expounded in Re St Peter, Draycott [2009] Fam 93, acknowledged that the burden of proof rested on the petitioners and recognised the above factors militating in favour of a faculty. Although there was no dire financial emergency within the parish, the parish only covered its annual expenditure each year by digging progressively more deeply into it reserves. The faculty was granted. [RA]

doi:10.1017/So956618X11000652

\title{
Re St Michael, Tilehurst
}

Oxford Consistory Court: Bursell Ch, April 2011

Deceased infant - teddy-bear-shaped memorial - pastoral considerations

The petitioner, whose child had died aged six months, sought a faculty permitting the introduction of a memorial, the central section of which would incorporate a detailed teddy bear embracing its top and side. The grave was situated in a part of the churchyard primarily used for children's and babies' burials. A number of memorials that did not comply with the churchyard regulations 